\title{
CODE-SWITCHINGS EMPLOYED BY TEACHER IN TEACHING ENGLISH
}

\author{
Ricky Andryanus Feldyan \\ STKIP PGRI Tulungagung \\ rikiyahan@gmail.com
}

\section{Moh. Hanafi}

STKIP PGRI Tulungagung

hanafiemoh@gmail.com

\begin{abstract}
This research was designed to analyze the use of code-swtiching by teacher in teaching English. The subjects of this research were some English teacher of the eleventh graders of SMK Perwari Tulungagung, majoring in Office Administration. This class was chosen because the teacher used two languages (English and Indonesian) in the teaching process. Because the students had difficulties in understanding the teacher' explanation if the teacher used English all the time, the teacher sometimes needed to code-switch to Indonesian during the teaching and learning process. The method used in this research is descriptive qualitative because the data are in the form of words and sentences. The techniques of collecting the data are observation, interview, and note taking. The findings show that the English teacher sometimes code-switch to Indonesian in the teaching and learning process in order to ensure that their students can really understand the explanations being given.
\end{abstract}

Keywords: Code-Switching, Bilingualism, Descriptive Qualitative, English Teacher

\section{INTRODUCTION}

English as an international language should be learnt by all people. This is the reason why English is taught in almost every school in Indonesia. The students are prepared to face the globalization era where English is used for communication in daily life. To make the process of teaching and learning of English successful, the teacher should make good preparation, including the plan, good strategies, as well as the materials. Besides that, the teacher is required to have good communication skill to make students easy to understand the material. In some schools in Indonesia, the teacher has to combine English with Indonesian. Although the teacher understands that teaching English subject in English will give good exposure to the students, it still seems impossible to do. The students had difficulties in understanding the teacher' explanation if the teacher is using English all the time. Therefore, combining English with the students' mother tongue is still considered important to do to ensure that the students can really understand the materials being taught. This language combining is also called as the case of Code-Switching.

"Code-switching is a bilingual communication strategy consisting of the alternate use of two languages in the same utterance, even within the same sentence (Hamers and Blanc, 1987:266)." Then, Rochayah and Djamil (1993:78) write, "Code mixing and code switching can actually happen only in the language of a bilingual." Moreover, Harding and Ridley (1986:51) view code-mixing and code-switching as "a phenomenon that is limited to bilingual situation, where bilinguals talk to other bilinguals and where they can have full communicative resources of both languages." Therefore, it is actually fine to have mixed or switched elements in the language of the teachers since both the teachers and the students have the access to both languages.

In this research, both the teacher and the students are considered bilinguals, and therefore, it is common for them to employ code mixing and code switching in their communication. "Bilinguals often find it easier to discuss a particular topic in one language rather than another" (Holmes, 1992:44). Similarly, according to Spolsky (1998:49), "bilinguals like to shift their languages for convenience". In this case, "speakers are usually fluent in both languages and regularly use both in the course of their daily routines" (Gumperz, 1982:59). This condition may be the basic reason why people do code mixing and code switching in their speech.

Even though code-mixing and code-switching have also been considered as a mark of linguistic decay, i.e. proof the inability of a bilingual to acquire two languages proportionally, or to keep them separated, Gumperz (1982:64) states that, "Code-switching does not necessarily indicate imperfect 
knowledge of the grammar. Only in relatively few passages is code alternation motivated by the speakers' inability to find words to express what they want to say in one code or the other code." In other words, though the teacher often employ code switchings in the language of their classroom instruction, it does not necessarily mean that their English is not good. Therefore, there must be some reasons for them for doing so.

Therefore, this research aims at answering two questions, they are: 1) What are the types of code-switching which are employed by the teacher in the process of teaching and learning in XI APK of SMK Perwari Tulungagung?; and 2) What are the functions of each type of code-switching which do the English teacher use in processs teaching and learning in XI APK of SMK Perwari Tulungagung?

\section{RESEARCH METHOD}

This research is a descriptive qualitative research. According to Creswell (2014, p.4), Qualitative research is the method of explorating and understanding the meaning of the persons or communities' perceptions in social problems or humanities. Moreover, descriptive studies are designed to obtain information concerning in the natural settings as it exists at the time of the research. In this research, the data were taken from the observasion sheet, questionaires, interviews, and field note taking. The observasion sheet was conducted in natural setting of SMK Perwari Tulungagung at 11th APK. To obtained the data, video recorder was used to record the teaching and learning process, and then the researcher used audio recorder to record the interview with the English teacher. Then, the field note taking was to obtain the data in the form of the transcription of the utterances which were recorded from the observation and the interview.

\section{FINDINGS AND DISCUSSIONS}

Types of Code Switchings Employed by the Teacher

The types of code-switching found through the observation in the classroom do not seem to fulfill all the code-switching types proposed by Hoffman (1991, p.112), namely; 1) Intra-sentential Switching, the one that occurs within a clause or sentence boundary; 2) Inter-sentential Switching, the one that occurs between a clause or sentences boundary; 3) Establishing Continuity Switching, the one that occurs to continue the utterance of previous speaker; 4) Emblematic Switching, which includes tags, exclamations, and certain inserted phrases; and 5) Involving a Change of Pronunciation, which occurs at the phonological level. After observing and analyzing the data in SMK Perwari Tulungagung, the researcher founds that the teacher only employ 2 types of code switchings, Intra-sentential switching and Inter-sentential switching.

Seventeen data of intra-sentential switching are found when the teacher employs intra-sentential switching from English to Indonesian. The example of Intra-sentential switching below is taken from XI APK in SMK Perwari, where the teacher switched from English to Indonesian.

\section{Today we will discuss tentang simple present}

(Switched between English [Bold] and Indonesian [in italics])

This expression happened in the beginning of the class activity. The utterance is categorized to intra-sentential switching because the teacher switched one or more words in one sentence. Based on the result of the interview, the English teacher admitted that the switching was intended to clarify the teaching material on that day. In the beginning, the teacher spoke in English then she inserted one Indonesian word, that was "tentang", in her sentence.

It's in gramatical klo gak ada article nya kurang tepat (Switched between English [in bold] and Indonesian [in italics])

In the data above, the expression happened when the teacher was explaining the material in the main activity. This expression is also categorized to intra-sentential switching. Then, based on the researcher's intervew to the English teacher, this switching was intended to give important information about the topic and to make the students understand the explanation well.

The second type of code switching is Inter-sentential switching. In inter-sentential switching, a speaker switches from one language to another between sentences. The results of the research show that the teacher employed 11 data on Inter-sentential switching during the teaching and learning activity. The teacher switched from English to Indonesian. In the data, there are some examples of teacher's utterance employing Inter-sentential switching.

Adjective, noun, adverb, yeeesss good job! Diikuti sama mereka

(Switched between English [in bold] and Indonesian [in italics]) 
This utterance happened in the beginning of the class, when the teacher explained the materials. In the data above, the teacher used two languages. English is used in the first sentence and followed by Indonesian in the next sentence. Based on the interview, the English teacher admitted that the switch was intended to make the students pay attention and get the information in the teacher's explanation.

So let's the answer the question, saatnya menjawab

(Switched between English [in bold] and Indonesian [in italics])

This sentence happened when a student has just finished a performance. Based on the results of the interview, the English teacher employed this swtich to give instruction to the student after his performance.

Functions of Code-Switching Employed by the Teacher

According Hoffman (1991), there are ten functions of code-switching; 1) To talk about a particular topic; 2) To quote somebody else; 3) To provide emphasis about something; 4) To make an interjection; 5) To repeat in order to clarify; 6) To express group identity; 7) To show intention of clarifying speech content for interlocutor; 8) To soften or strengthen a request or command; 9) To meet a real lexical need or to compensate for lack of an equal translation; and 10) To exclude others when a comment is intended for an exclusive audience. After observing and interviewing the teacher in the class, the researcher can conclude that there are some of the 10 functions of code switching occur in the utterances of the teacher, they are; 1) To talk about a particular topic; 2) To provide emphasis about something; 3) To repeat in order to clarify; and 4) To soften or strengthen a request or command.

The first reason is to talk about a particular topic. Related from the reseacher's observation, it aims to make the students enjoy the teaching and learning activity. The teacher switched her code to talk about particular topic several times. The data below is the example of code switching done by the teacher to talk about a particular topic.

Example 1:

Didn't you go somewhere, maybe pantai or belanja with your family or friends?

Example 2;

Sometimes, when we have to speak kita lupa nambahin 's' or 'es', lupa karena gak terbiasa, but we have to make it, kalian harus membiasakannya.

In the utterances above, the teacher used two languages, English and Indonesian. She switched from English to Indonesian because she wanted to talk about particular topic and get the responses. Based on the observation during the class activity, the teacher sometimes needs to refresh the situation, therefore, the teacher changed her code. All of the utterances talking about the many different topics, some of which is not related of the lesson material. The aim is to make the situation relax and enjoyable.

Sometimes, the teacher also employs code switching to show emphasis. From the data gathered through observation, the researcher inferred that the English teacher switched her code, usually from English into Indonesian, whenever she tried to get her student's attention.

Example 3:

Oke for example; Agista is cute, jadi cute here is adjective

Example 4:

So we make glasses, for ' $\mathrm{H}$ ' by watch jadinya watches, box jadinya boxes. For 'O', potato jadinya potatoes

In those examples, the sentences occur when the teacher was explaining the materials and give some examples to the students. The teacher used Indonesian to show the correct answers of the examples.

In some cases, the teacher actually faces some problems in teaching English. Since the students almost never use English in their daily interaction, they can hardly understand the intructions or words which were in English. Therefore, in order to make the students understand the material and increase their English ability, the teacher need to provide the clarification of the English utterances in Indonesian. 
Example 5:

In your book, not in a piece of paper, jangan di lembaran!

Example 6:

So let's the answer the question, saatnya menjawab

The data above showed that the teacher used two languages; English and Indonesian. Those utterances were produced in the main period of the class activity when the teacher gave the task and then the student practiced in front of class. In example 5, The student asked to the teacher about the task which they have to do, but the teacher answered in English. However, she then clarified her instruction in Indonesian in order to make the student understand. In example 6, the utterances happened when a student was performing. The teacher was giving direction to the student, that they were supposed to go to the next section. The teacher prefers English, but then she switched to Indonesian because she wants to clarify her instruction.

The last function of teacher's code switching is to soften or strengthen a request or command in her utterance. During the teaching and learning activity, some students did not listen to the teacher's command. In conducting a teaching and learning activity, the teacher repeated her utterances several times.

\section{Example 7:}

Oke i give you ten minutes to finish, kerjakan....!

The data shows that the teacher used two languages in her utterance when she wants to give some instructions for the students. The teacher strengthen her command which was initially in Indonesian by switching in to English. In this situation, she switched her code to emphasize her command.

From all of the examples, we can see that code-switchings are actually mainly done unintentionally. The teacher, despite her mastery of English, is still an Indonesian native speaker. Therefore, it is very natural if the influence of her first language is still very strong. This conclusion supports a statement by Spolsky (1998:49), who says "bilinguals like to shift their languages for convenience". In this case, the teacher feels convenient to involve some words from her native tongue because those words are needed for some reasons. For example, the level of English competence of the students in a classroom is of course varied. Therefore, in order to assure that the achievement of all of the students in the classroom is more or less similar, those who are weak need to be assisted. One of the ways to assist them is by simplifying the language, or using their first language. This supports Kern's findings as quoted by Macaro (2001:531) who had revealed "a number of advantages of using the L1 in order to reduce memory constraints, convert text into more familiar terms, and avoid losing track of meaning."

\section{CONCLUSIONS}

Based on the results of the data analysis and the findings which were presented in the previous chapter, there are two types of code-swtichings that the teacher uses during the teaching and learning of English subject at XI APK in SMK Perwari Tulungagung. The intra-sentential switching occurs in 17 data and the inter-sentential switching occurs in 11 data.

For the functions of code-switchings employed by the teacher during the teaching and learning of English, they are as follows; 1) To talk about a particular topic: 2) To provide emphasis about something; 3) To repeat in order to clarify; 4) To soften or strengthen a request or command, this function happened in differents situation during learning and teaching English.

It can now be concluded that the occurrence of code-switching in the language of classroom instruction is actually beneficial. Despite the facts that some previous studies believe that the use of code-mixing and code-switching in the classroom will only "spoil" the students and undermine the learning process, this research shows that code-switching can help the students to get a better achievement in the learning process. Therefore, although some people may think that when a teacher involves some code-switchings in the language of their classroom instruction, it is due to their decreasing quality of English proficiency, or a mark of linguistic decay, this research strongly rejects that. This research supports the use of code-mixing and code-switching as a teaching strategy, which is for the sake of the students' better achievement.

\section{REFERENCES}

Cresswell, Jhon W. 2014. Research Design, 4th Edition. California: SAGE Publucation.

Gumperz, John J. 1982. Discourse Strategies: Studies in Interactional Sociolinguistics 1. New York: Cambridge University Press. 
Hamers, F.J. \& Blanc, H.A.M. 1987. Bilinguality and Bilingualism. Cambridge: Cambridge University Press.

Harding, E. \& Ridley, P. 1986. The Bilingual Family: A Handbook for Parents. Melbourne: Cambridge University Press.

Hoffman, Charlotte. 1991. An Introduction to Bilingualism. London \& New York: Longman Inc.

Holmes, Janet. 1992. An Introduction to Sociolinguistics. New York: Addison Wesley Longman Inc.

Macaro, Ernesto. 2001. Analyzing Student Teachers' Code-switching in Foreign Language Classrooms: Theories and Decision Making. The Modern Language Journal, Vol.85, No.4. Malden: Blackwell Publishers, co.uk.

Rochayah \& Djamil, Misbach. 1993. Sosiolinguistik. Jakarta: Depdikbud.

Spolsky, Bernard. 1998. Sociolinguistics. Hong Kong: Oxford University Press. 